\title{
“O RAP É UMA COISA QUE CONECTA, TÁ LIGADO?!": RESSIGNIFICANDO CONTEXTOS DE JOVENS EM CUMPRIMENTO DE MEDIDA SOCIOEDUCATIVA ${ }^{1}$
}

\author{
"RAP IS A THING THAT CONNECTS, IS IT LINKED?!": RESSIGNIFICATING \\ CONTEXTS OF YOUNG PEOPLE IN COMPLIANCE WITH SOCIO- \\ EDUCATIONAL MEASURE
}

\author{
Mayara dos Santos ${ }^{2}$ \\ Tiago Pereira Leite ${ }^{3}$
}

RESUMO: O presente trabalho tem como propósito uma reflexão sobre o rap como possibilidade educativa, que contribui na ressignificação do contexto de jovens e adolescentes em cumprimento de medida socioeducativa na cidade de Cascavel - PR. Objetiva-se uma discussão acerca do rap como alternativa pedagógica em espaços de institucionalização, tratando de questões referentes à noção de juventude e culturas juvenis e também a relação entre juventude e violência. Na tentativa de compreender como o rap pode ser utilizado como instrumento educativo, realizou-se uma pesquisa de campo no Centro de Referência Especializado de Assistência Social - CREAS II na cidade de Cascavel - PR, tendo como ponto principal a observação da Oficina de Rimas. Ademais, foram realizadas entrevistas com o oficineiro e com a pedagoga do centro. Na busca de verificar de que forma o rap tem contribuído para ressignificar contextos, utilizamos como referência as letras de rap compostas pelos adolescentes. Concluímos destacando que o gênero musical em questão é de grande influência no que se refere à formação de identidades e um importante elemento de constituição do imaginário sobre a vida do jovem na periferia.

PALAVRAS-CHAVE: Juventude; Culturas Juvenis; Identidades; Rap; Educação.

ABSTRACT: This paper aims to reflect on the rap as an educational possibility, which contributes to reframe the context of youth and adolescents in compliance with socioeducational measures in the city of Cascavel - PR. The objective is to discuss about rap as a pedagogical alternative in spaces of institutionalization, addressing issues related to the notion of youth and Youth Cultures and also the relationship between youth and violence. In an attempt to understand how rap can be used as an educational tool, a field research in Specialized Reference Center for Social Assistance- CREAS II was held in the city of Cascavel- PR, having as the main point the observation of Rhymes Workshop. Moreover, we also conducted interviews with the work shopper and the pedagogue of the center. In seeking to verify how rap has contributed to reframe contexts, we use as reference the rap lyrics composed by the teenagers. We concluded by pointing out that the musical genre in question is of great influence in relation to the formation of identities and an important imaginary constitution element about the life of the youth in the periphery.

KEYWORDS: Youth - Youth Culture - Identity - Rap - Education.

\footnotetext{
${ }^{1}$ Esse artigo é resultado de pesquisa durante o Curso na graduação em Pedagogia pela Universidade Estadual do Oeste do Paraná, no ano de 2015. Sofreu alterações com vistas à publicação.

${ }^{2}$ Aluna do Mestrado em Educação da Universidade Estadual do Oeste do Paraná - Campus de Cascavel. (e-mail shu_mayara@hotmail.com)

${ }^{3}$ Mestre em Ciências Sociais pela Universidade Estadual do Oeste do Paraná - Campus de Toledo. Professor colaborador na Unioeste/Cascavel. Doutorando em Ciências Sociais Pela Universidade do Vale do Rio dos Sinos (UNISINOS) (e-mail: tpleite@ hotmail.com)

Revista Labor Fortaleza/CE, jan/jul 2017 Vol. 01, nº 17, p. 42-61 ISSN 1983-5000
} 


\section{INTRODUÇÃO}

O presente trabalho tem o propósito de analisar o rap como possibilidade educativa e que contribui na ressignificação do contexto de jovens e adolescentes em cumprimento de medida socioeducativa na cidade de Cascavel - PR.

Dentre as inúmeras manifestações culturais existentes, optamos por estudar a música, pois essa atividade é em grande medida um elemento de expressividade entre a juventude. Tomamos aqui como referência o rap, gênero musical emergente do movimento hip hop.

Rap é a abreviação das palavras Rhythm and Poetry que significa Ritmo e Poesia. Ele é um dos elementos do movimento hip hop. Hip hop é uma expressão que vem do inglês, gramaticalmente significa pular e mexer os quadris ( hip = quadril, hop = saltar), porém o conceito é utilizado para referir-se a uma manifestação tratada como movimento social e cultural. Os primeiros acontecimentos foram nos Estados Unidos no final dos anos 60 e início dos anos 70, especificamente na periferia de Nova Iorque. O movimento é composto por cinco elementos sendo: Breaking (dança), Grafite (arte visual), DJ (disco jóquei), MC (Mestre de Cerimônia) e o conhecimento. A junção do DJ com o MC forma o rap.

A opção em pesquisar o gênero musical rap partiu da pertinência que ele possui perante seu público, pois "mesmo o hip hop sendo um movimento consolidado no Brasil, presente nas escolas, na mídia e nas pesquisas acadêmicas, seus produtores, muitas vezes, ainda são estigmatizados" e diríamos que talvez não só os produtores, mas também, os ouvintes (MACEDO, 2010, p.173).

O rap foi por muito tempo considerado música de baixa qualidade e, por isso, não era veiculado pelos meios de comunicação de massa, pois apresentava uma linguagem marcada pelo uso de 'palavrões', gírias e expressões comuns aos moradores de periferias. Nesse contexto, não são poucos os 'chavões' de que o rap seja música de marginal, bandido e drogado sendo, portanto, suas letras apologia ao crime, drogas e violência. Porém, após um processo de mundialização e propagação do movimento hip hop de modo geral, o rap passou a ser compreendido como um instrumento de manifestação cultural popular. 
Enquanto manifestação cultural, o hip hop e o rap adquiriram uma perspectiva de prática educativa informal e não formal ${ }^{4}$, ganhando muito espaço nos últimos anos na produção acadêmica. Aliado as temáticas de formação de identidades e educação o rap e o hip hop de modo geral, vêm sendo objeto de estudo em inúmeros trabalhos de graduação, dissertações e teses que foram utilizadas como aporte teórico nesta pesquisa. Vários são os autores que afirmam e apontam as possibilidades educativas que podem partir dessa cultura, principalmente para a juventude da periferia, devido à identificação do jovem com as práticas inerentes ao movimento, que historicamente é proveniente do contexto de grupos marginalizados.

$\mathrm{Na}$ tentativa de compreender como o rap pode ser utilizado como instrumento educativo, realizou-se uma pesquisa de campo no Centro de Referência Especializado de Assistência Social - CREAS II - na cidade de Cascavel - PR, tendo como ponto principal a observação da Oficina de Rimas. Além dos dados da investigação de campo, esse trabalho trata acerca dos entendimentos sobre o conceito de juventude como categoria social e as culturas juvenis como meio de expressão da juventude contemporânea.

Aborda-se, ainda que brevemente, o rap em sua perspectiva educativa, fazendo uma análise de autores que já estudaram sobre o assunto, estabelecendo uma relação entre o rap e a formação de identidades do jovem da periferia. Posteriormente, faz-se uma explanação sobre a relação entre juventude e violência, explicitando a juventude enquanto um grupo social vulnerável na sociedade brasileira, estabelecendo um panorama entre o jovem e a prática de delitos.

A parte final desse trabalho é o momento em que - para além de apresentar o campo de pesquisa (Centro de Referência Especializado de Assistência Social - CREAS II) e explicitar sua função em relação ao acompanhamento de jovens e adolescentes em cumprimento de medida socioeducativa na cidade de Cascavel - abrimos uma discussão sobre a oficina de rima desenvolvida neste espaço, estabelecendo um debate entre as abordagens teóricas apresentadas e os dados levantados na observação da oficina, de modo analisar se o rap, principal agente da prática educativa da oficina, pode contribuir na ressignificação do contexto de tais jovens e adolescentes.

\footnotetext{
${ }^{4}$ Os conceitos de educação informal e não formal são utilizados tendo como referência a autora Maria Glória Gohn, a partir da obra "Educação não formal e cultura política: impactos sobre o associativismo do terceiro setor" (2011).

Revista Labor Fortaleza/CE, jan/jul 2017 Vol. 01, nº 17, p. 42-61 ISSN 1983-5000
} 


\section{JUVENTUDE, CULTURAS JUVENIS E IDENTIDADES}

Historicamente a juventude é considerada uma categoria de difícil definição, que adquiriu ao longo dos tempos diferentes denotações de acordo com a área em que é estudada. Entendida como fase de transição e de busca pela identidade, esse grupo comumente é relacionado a problemas sociais de diversas naturezas.

Uma parcela significativa das definições e estudos sobre a juventude partem de abordagens com um aspecto linear, fazendo descrições superficiais do que é ser jovem, ora com enfoque apenas na questão da condição social ora tão somente na perspectiva da delimitação etária.

Não é nossa intenção descaracterizar ou desconsiderar as abordagens do estudo de jovens que são predominantemente etárias, todavia, acredita-se que a designação do ser jovem limitada apenas à idade, refere-se muito mais a características biopsicológicas de desenvolvimento e acabe por não levar em consideração fatores sociais, econômicos e culturais que influenciam diretamente o jovem na formação da identidade. Não se quer, contudo, determinar que somente a definição do jovem no aspecto social é correta, mas verifica-se a necessidade de equilíbrio entre ambas no que se refere ao estudo da juventude, cuidando para “(...) não considerá-la mais presa a critérios rígidos, mas como parte de um processo mais amplo, que ganha contornos específicos no conjunto das experiências vivenciadas pelos indivíduos em seus contextos sociais" (DAYRELL, 2003, p. 42).

Considerou-se o termo juventude em seu aspecto sociológico, pois concorda-se com Esteves e Abramovay (2008) de que:

(...) não há somente um tipo de juventude, mas grupos juvenis que constituem um conjunto heterogêneo, com diferentes parcelas de oportunidades, dificuldades, facilidades e poder nas sociedades. Assim, a juventude, por definição, é uma construção social, ou seja, a produção de uma determinada sociedade originada a partir das múltiplas formas como ela vê os jovens, produção esta na qual se conjugam, entre outros fatores, estereótipos, momentos históricos, referências múltiplas, além de diferentes e diversificadas situações de classe, gênero, etnia, grupo, etc. (ESTEVES E ABRAMOVAY, 2008, p. 4).

Considerando a complexidade que abrange a noção de juventude, em se tratando de grupos juvenis, pode-se dizer que existem juventudes no plural, pois as manifestações do que é ser jovem são as mais diversas. Ainda que muitos aspectos biopsicológicos sejam 
característicos do sujeito juvenil, enquanto categoria social partiu-se da premissa da não existência de uma uniformidade, ainda que se fale sobre indivíduos de uma mesma idade.

Diante das inúmeras expressões que tentam definir os agrupamentos de jovens, optou-se pelo conceito de culturas juvenis. Magnani (2005) parafraseando Feixa (2004) pondera que:

(...) o termo "culturas juvenis" aponta mais para as formas em que as experiências juvenis se expressam de maneira coletiva, mediante estilos de vida distintivos, tendo como referência principalmente o tempo livre. Esses "estilos distintivos", identificados por meio do consumo de determinados produtos da cultura de massa, como roupas, música, adereços, formas de lazer etc., remetem à ideia das "subculturas" (...) (MAGNANI, 2005, p.176) .

A utilização do conceito culturas juvenis se dá pela abrangência que o mesmo compõe, pois se refere à representação de "modos de vida específicos e práticas cotidianas que expressam um conjunto de significados que sinalizam o pertencimento a um determinado grupo" (DAYRELL apud SILVA; SILVA, 2012, p. 10).

Enquanto práticas cotidianas, as culturas juvenis remetem-se a processos de socialização, por meio dos quais o sujeito jovem se apropria de determinados valores que são expressos em atitudes e comportamentos que o apontam como sendo integrante de um grupo social específico. Entretanto, compor um grupo social por compartilhar de suas práticas e representações "não reduz o jovem a esse vínculo e ao que pode ser pensado a partir da posição desse grupo em um espaço social” (DAYRELL, 2002, p.121).

As culturas juvenis são dinâmicas e heterogêneas, o jovem que integra um grupo social não necessariamente está excluso dos demais grupos. As relações de trocas entre as várias culturas e estilos são constantes, nesse contexto, o sujeito pode constituir diferentes grupos e a partir da influência que recebe de cada um deles constrói sua identidade e um estilo próprio. $\mathrm{O}$ “(...) jovem tem acesso a múltiplas referências culturais, constituindo um conjunto heterogêneo de redes de significado que são articuladas e adquirem sentido na sua ação cotidiana" (DAYRELL, 2002 p. 121).

A socialização e o acesso às diferentes culturas também estão relacionados às condições sociais em que os jovens se encontram. Ainda que isso não seja fator determinante na separação dos grupos juvenis, a condição social corrobora com as possibilidades de

\footnotetext{
${ }^{5}$ Magnani não se apropria e não utiliza o termo cultura juvenis, o autor parte de outra concepção a qual denomina circuitos de jovens. Para maiores informações ver "Os circuitos dos jovens urbanos" (MAGNANI, 2005).

Revista Labor Fortaleza/CE, jan/jul 2017 Vol. 01, nº 17, p. 42-61 ISSN 1983-5000
} 
consumo, e influencia também nas relações sociais que se estabelece, seja no trabalho ou na escola, mas principalmente no que diz respeito às práticas de lazer. Desse modo as experiências vivenciadas pelos jovens das classes menos favorecidas nem sempre serão as mesmas que a de jovens das classes mais abastadas e vice-versa.

Dentre as inúmeras atividades culturais existentes - expressas através do corpo, roupas, comportamentos, linguagem, etc. - optou-se por estudar a música, pois essa atividade cultural é em grande medida um elemento de expressividade entre a juventude, seja ela da periferia ou não.

Como essa pesquisa se pauta no estudo de grupos de jovens provenientes, sobretudo de áreas pobres da cidade de Cascavel - PR, toma-se como referência o rap, gênero musical emergente do movimento hip hop, o qual possui evidente representatividade junto aos jovens das periferias brasileiras.

O rap pode ser designado como uma cultura juvenil e meio de expressão da juventude, à medida que sua produção cultural resulta na constituição de grupos que se integram e compartilham práticas e representações comuns.

Assim, o RAP (...) como manifestação jovem, (...) passa a ser entendido como produto da sociabilidade juvenil, reveladora de uma forma peculiar de apropriação do espaço urbano e do agir coletivo, capaz de mobilizar jovens (...) em torno de uma identidade comum (SPOSITO, 1994, p. 167).

As culturas juvenis de modo geral são meios pelos quais o jovem se apropria de valores e significados construindo sua identidade. A formação da identidade está relacionada à apropriação sentidos vinculados às diferentes culturas juvenis. E o rap caracterizado como uma cultura juvenil é dotado de significados e, na medida em que é assimilado enquanto um bem simbólico por um grupo de pessoas que compartilha de tais valores e significações, o rap cria identidades sociais entre os ouvintes.

Fala-se de identidades, no plural, pois compreende-se que a formação de identidade pelo jovem não ocorre de forma unificada. "O sujeito assume identidades diferentes em diferentes momentos, identidades que não são unificadas ao redor de um 'eu' coerente" (HALL, 2006, p.13).

Embora se trate de um estilo de vida que possui características próprias como é o caso do hip hop, não é possível afirmar que todos os que fazem parte do movimento constituam uma identidade de igual forma, ainda que se identifiquem por fazerem parte do mesmo meio e compartilhem ideias, isso não os torna iguais. Assim, parte-se da premissa que 
as identidades não são fixas sendo, portanto "transformadas continuamente em relação às formas pelas quais somos representados ou interpelados nos sistemas culturais que nos rodeiam" (HALL, 2006, p.2).

Embora o rap permita a constituição de uma identidade juvenil (...) o processo de identificação entre o rap e seu público, assim como a própria constituição de identidades a partir do movimento rap, não se esgotam em definições como "jovens de atitude", "jovens conscientes" ou como "vozes da periferia". Neste sentido, embora o hip hop e o rap possuam em sua essência um caráter unificador, sobretudo da periferia, o rap também é por excelência ressignificação. (...) O que pretendemos considerar, nesse sentido, é que o rap não é um movimento homogêneo, portanto a identidade que ele constitui também não o é (MACEDO, 2010, p.89).

A constituição de identidade e o processo educativo do rap - como produto de consumo - ocorrem por meio da propagação de ideias e significações, expressas não só no discurso presente nas músicas, como também pelo compartilhamento de realidades, comportamentos, atitudes, linguagem, onde há uma afirmação identitária dos sujeitos ouvintes com aquilo que é transmitido.

Pelo aspecto de sociabilidade que lhe é imanente, o rap enquanto estilo de vida, designa uma prática educativa informal. De acordo com Gohn (2011, p.107) “A educação informal decorre de processos espontâneos ou naturais, ainda que seja carregada de valores e representações (...)".

A educação informal proveniente de processos espontâneos diz respeito a formas de socialização a que estamos submetidos. A socialização de acordo com Berger e Berger apud Viana (2009, p. 146) é o processo por meio do qual os sujeitos formam sua identidade.

No início desse artigo, o conceito de socialização foi relacionado às culturas juvenis enquanto práticas cotidianas e o rap apontado como sendo uma cultura juvenil. Nesse contexto pode-se afirmar que o gênero musical em questão, enquanto parte do processo de socialização, resulta na formação de identidade, uma vez que essa ocorre por meio das relações sociais que os sujeitos estabelecem sendo, portanto, um instrumento educativo informal.

Percebendo que existe uma identificação dos jovens com o rap - sobretudo o jovem oriundo da periferia - e que este se caracteriza como uma esfera da sociabilidade juvenil, muitos espaços institucionais vêm se utilizando do gênero musical em questão como uma prática educativa. 
Quando o estilo musical é utilizado com uma intencionalidade de dados em prol de objetivos específicos, ele passa a evidenciar a efetivação de uma prática de educação não formal, possuindo uma finalidade com sua utilização, que transcende 'uma educação 'em si', construída historicamente pelo hip hop" (FIUZA; MACEDO, 2013, p. 19), e relaciona-se aos objetivos que a instituição pretende alcançar fazendo uso do rap.

De fato viu-se o quanto é crescente nos últimos anos a apropriação do rap e do hip hop de modo geral como prática educativa por espaços, instituições, entidades e organizações diversas, principalmente no que se refere ao trabalho com a juventude. Podemos citar várias organizações que se apropriaram do rap como mecanismo educacional como a Central Única das Favelas (CUFA), Centros Culturais de Juventude (CCJ), Centros de Artes e Esportes Unificados (CEUs), Casas de Cultura, Projovem adolescente e o local de concretização dessa pesquisa - o Centro de Referência Especializado de Assistência Social (CREAS II) na cidade de Cascavel.

\section{JUVENTUDE E VIOLÊNCIA}

A abordagem acerca da relação entre juventude e violência é bastante polêmica e controversa, consistindo em um tema que vem sendo muito discutido pela academia.

Partindo do entendimento de que a juventude seja uma construção social, compreende-se, portanto, que assim como ocorrem mudanças no que diz respeito à noção de juventude "também as representações que se fazem sobre os jovens têm se alterado historicamente, expressando diferentes sentidos para esse grupo social" (FACHINETTO, 2010, p. 62).

A juventude conjuga inúmeros estereótipos relacionados a problemas sociais de diversas naturezas. As associações pejorativas oscilam entre a compreensão do sujeito jovem como "ser problema" ou o "futuro do país". Em se tratando de jovens provenientes de áreas periféricas das grandes cidades, entende-se que o que predomina é a caracterização marcada fortemente pelos aspectos negativos ligados a problemas, delinqüência, rebeldia e práticas de violência.

De fato, a violência urbana é um fenômeno social e uma realidade que explicitamente inunda os meios de comunicação de massa. Basta ligar a televisão ou navegar nas redes sociais para chocar-se com inúmeras notícias de acontecimentos violentos em 
diversas partes do mundo, geralmente os jovens são apontados como principais vítimas e autores das práticas de violência e criminalidade.

As tentativas de explicação da vulnerabilidade juvenil com relação à violência e a prática de delinquência são inúmeras. Gadea (2013, p. 9) aponta que a violência pode emergir como uma forma de linguagem e sociabilidade do jovem, o que denota 'a integração negada' ou 'postergada' desses sujeitos em relação ao meio social.

(...) a violência pode aparecer em sua forma anômica para contradizer uma ordem estabelecida em sociedades que não aceitam diferentes valores e comportamentos; nesse caso, ela pode surgir como forma de confronto, de denúncia e de resistência para a construção de ordenamentos sociais mais justos. (SCHROEDER, 2008, p. 6).

De acordo com os autores supracitados, a relação entre juventude e violência pode ser explicada, por exemplo, como uma forma de expressão dos sujeitos jovens a falta de políticas públicas a eles destinadas. Grande parte dos projetos voltados para a juventude reitera as "problemáticas da vulnerabilidade, do risco e da violência, ou seja, (...) aparecem como um aspecto da questão social e não a partir da constituição de um espaço de visibilidade da condição juvenil moderna (...) (SPOSITO apud TITON; ZANELLA, 2010, p. 37).

$\mathrm{Na}$ falta de opções de lazer, de boas escolas e de trabalho, os jovens que vêm tendo seus direitos negados dia após dia encontram na violência uma forma de serem vistos e reconhecidos.

A violência é uma forma (...) de afirmação da invisibilidade e da exclusão
compartilhada por jovens de várias esferas culturais. É por tais motivos que
se deve situar a violência juvenil não como exclusividade de setores situados
na periferia das cidades. A violência entre as gangues da periferia,
diferentemente de outros modos de expressão da violência juvenil,
representa uma tentativa de demarcação e expressão da existência de todos
aqueles que se sentem banidos e exilados, seja das vantagens econômicas,
seja dos valores de uma ordem social segmentada e excludente
(DIÓGENES, 1998, p. 241).

“Os meios de comunicação apresentam duas opções sobre a construção simbólica da juventude: por um lado, ancorada no universo da moda e da publicidade, e por outro, ligado à violência e à delinquência" (GADEA, 2013, p. 4). Ocorre, porém, que a mídia em suas abordagens sobre os conflitos que caracterizam a emergência dos jovens no país, acaba criando uma visão estigmatizada desses sujeitos, e isso é facilmente observado nos noticiários que comumente vêm carregados de preconceitos e estigmas, para explicar as práticas de violência envolvendo jovens, como resultado de uma etapa problemática da vida. 
É interessante perceber que uma parcela significativa da sociedade, influenciada pela mídia, considera uma aparente "indissociabilidade" do contexto juvenil com a questão da violência. $\mathrm{O}$ fato de a juventude ser um período marcado pelo aspecto da formação da identidade, transitoriedade e disposição a correr riscos, faz com que erroneamente a sociedade postule ao jovem uma 'naturalidade' do envolvimento com o mundo do crime, principalmente quando se fala de jovens pobres e negros.

É certo que a juventude é uma categoria social considerada vulnerável no país. Os conflitos que caracterizam a emergência dos jovens no Brasil, para além da falta de oportunidades de trabalho e lazer, fatidicamente são a exposição à violência e o envolvimento com a criminalidade, todavia os jovens não são os autores dos mais alarmantes índices de violência.

No mapa da violência do ano de 2014 é possível observar que a taxa de homicídios de jovens no Brasil entre o ano de 2000 a 2012 cresceu notoriamente. Diante disso, podemos dizer que a exposição do sujeito jovem a violência acontece mais como vítima de atos violentos do que como autor de práticas de violência.

Ainda que o sujeito jovem cometa "crimes" que pela lei n. 8.069, de 13 de julho de 1990 considera-se ato infracional a porcentagem de jovens envolvidos com delitos é "de 8 a $10 \%$ do total, ou seja, o "mundo adulto" é o principal protagonista da denominada delinqüência urbana nas grandes e medianas cidades do mundo" (GADEA, 2013, p. 12). O estigma de que a juventude é a categoria social de maior envolvimento com a criminalidade é uma falácia. A mídia é o principal agente propulsor dessa ideologia, "cristalizou-se um imaginário social no qual se associa o segmento juvenil - em especial as classes populares - à condição de protagonistas da violência e, mais ainda, à constituição de uma ameaça indiscriminada a toda a sociedade" (BRASIL apud SANTOS et al, 2012, p. 523).

Prevê-se a necessidade de elaboração de políticas públicas voltadas ao segmento juvenil que dê a eles visibilidade e lugar na sociedade e que verdadeiramente sejam promotoras dos direitos dos sujeitos jovens. Mesmo para casos de institucionalização quando se trata de adolescentes infratores entendemos que o cumprimento das medidas socioeducativa deva ir além da instauração de controle e de disciplinamento da conduta. É nessa perspectiva que visualizamos o rap, uma forma de sociabilidade e cultura juvenil como uma alternativa na ressignificação do contexto de jovens e adolescentes. 


\section{O CENTRO DE REFERÊNCIA ESPECIALIZADO DE ASSISTÊNCIA SOCIAL (CREAS II) E A OFICINA DE RIMAS}

Na tentativa de analisar o rap como instrumento educativo na ressignificação do contexto de jovens e adolescentes que cumprem medida socioeducativa, realizamos uma pesquisa de campo, associando as observações com o referencial bibliográfico estudado.

A pesquisa ocorreu no Centro de Referência Especializado de Assistência Social (CREAS II) na cidade de Cascavel PR. O centro consiste em uma unidade pública que presta serviços de atenção socioassistencial e acompanhamento a adolescentes e jovens de 12 a 18 anos incompletos em cumprimento de Medida Socioeducativa de Liberdade Assistida (LA) e Prestação de Serviços à Comunidade (PSC). O Estatuto da Criança e do adolescente (ECA) é o documento que norteia o cumprimento de medida socioeducativa pelo adolescente infrator. O período de cumprimento da medida varia conforme a infração cometida e não é determinada pelo centro, mas judicialmente.

De acordo com as informações obtidas com a pedagoga do Centro, no que se refere aos atos infracionais que levaram a aplicação da medida socioeducativa tem-se que a maior incidência de infrações tanto para PSC quanto LA é:

- Associação para o tráfico

- Dirigir veículo automotor sem permissão para dirigir ou habilitação

- Lesão corporal leve

- Furto

- Receptação simples

- Tráfico ilícito de entorpecentes

Grande parte das medidas é cumprida em nível de PSC, sendo que por meio das observações realizadas, foi possível constatar que as infrações são cometidas em grande medida por adolescentes do sexo masculino com idade entre 14 e 17 anos. Há que se considerar ainda, que o discurso midiático sobre a relação dos jovens com a prática de crimes ‘pesados' é uma falácia considerando os dados obtidos durante a pesquisa.

Está fartamente demonstrado no mundo que o delito protagonizado pela população jovem e menor de idade (contemplando os homicídios, o furto, o roubo e a lesão corporal) é de 8 a $10 \%$ do total, ou seja, o "mundo adulto" é o principal protagonista da denominada delinqüência urbana nas grandes e medianas cidades do mundo. Dessa maneira, é falsa tal associação. Por outro lado, a "criminalização das drogas", considerando-se que o consumo de maconha, por exemplo, é produto de uma juventude que lida com a 
ilegalidade e que conspira contra a "ordem cidadã", tem-se estabelecido como discurso estigmatizante para as sociabilidades juvenis, o lazer e a própria experiência jovem. Nesse sentido, influenciados pela megalomania televisiva de muitos programas, grande parte da população assume como "real" dados e acontecimentos que adquirem capacidade construtiva de percepções que se admitem como emanadas do "mundo real", percepções muitas vezes fundamentada em boatos, fofocas, "diz que me diz", etc. (GADEA, 2013, p. 12).

O CREAS II realiza o atendimento dos adolescentes de forma sistemática, com frequência mínima semanal que garanta o acompanhamento contínuo e possibilite o desenvolvimento do Plano Individual de Atendimento (PIA). O trabalho na unidade está configurado a partir de atividades socioeducativas de atendimentos individuais, familiares, grupais e de interação com a comunidade. Dentre as várias atividades desenvolvidas no centro o foco da pesquisa de campo foi no acompanhamento de uma das oficinas socioeducativas: a oficina de rima. A instituição oferece um total de 11 oficinas, sendo que 3 delas são específicas de LA e 8 específicas de PSC.

Os adolescentes participam de todas as oficinas oferecidas na instituição de acordo com a modalidade da medida socioeducativa a qual devem cumprir. Todas as oficinas desenvolvidas contam com um plano de trabalho, em que se prevêem os objetivos a serem alcançados na oficina mediante o PIA.

$\mathrm{Na}$ oficina de rima são atendidos somente adolescentes em cumprimento de PSC. A oficina iniciou no CREAS II em outubro 2014, sendo ministrada por Geovani de Oliveira, conhecido como Jhow. O jovem é rapper desde 2011 e tornou-se militante do hip hop por meio de atividades realizadas na praça Wilson Joffre em Cascavel - PR.

De acordo com a pedagoga da instituição, o início de novas oficinas depende da contratação dos oficineiros, sendo que são oferecidas de acordo com a área de conhecimento do profissional contratado. A opção por abrir a oficina de rima foi colocada pensando numa proposta socioeducativa a partir de uma forma de sociabilidade dos adolescentes: o gênero musical rap.

A oficina ocorre em uma sala anexa ao ginásio de esportes da instituição. São atendidos em média de 10 a 15 adolescentes por dia. O trabalho desenvolvido pelo oficineiro objetiva em conjunto com as demais oficinas, ser um meio de reflexão dos adolescentes sobre a prática de infrações como porta de entrada para o crime. Nas palavras de Jhow a oficina visa "mostrar aos manos que o crime não compensa que existem outras formas de se expressar, e o rap é uma delas, o rap é uma arma contra o sistema, o crime é cadeia ou caixão”. 
A maioria dos adolescentes demonstrava envolvimento com as atividades propostas, poucos evidenciavam desinteresse ou se recusavam a realizar o que o oficineiro propunha. Em entrevista gravada com o oficineiro questionei sobre a receptividade dos adolescentes em relação à oficina e de acordo com ele:

Isso é uma coisa que tipo é de boa, já é suave, isso ai (o rap) é um convite ali de ficar tudo numa boa memo, assim... que muitos moleques têm muitos problemas com certos educadores, comigo num... tipo nunca teve assim nenhum problema maior assim, porque o rap já é uma coisa que conecta tá ligado, já é uma coisa que tipo é um meio, um meio termo de facilitar o acesso, os cara já se identifica, eu faço uma rima pá os cara fala faz de novo eu quero gravar, não sei o que, pá, muito massa e tal, então é que também é muito da realidade deles o rap (...) (JHOW, Oficineiro de Rima no CREAS II)

As atividades desenvolvidas na oficina pautam-se em:

- Leitura e interpretação de poesias/raps

- Discussões e debates sobre temas elencados em nas letras de rap.

- Assistir documentários, videoclipes e filmes sobre o rap, hip hop e crime.

- Composição de letras de rap

Nas discussões e debates que presenciei, os adolescentes expunham seus pontos de vista sobre temas abordados em poesias (raps) como, violência, crime, preconceito, drogas, desigualdades e a vida na periferia de modo geral. De acordo com o oficineiro:

a gente ali tenta fazer eles refletir pelo menos pra valorizar a vida, falar não minha vida vale mais que só ganha um troco rapidão, ir preso ou morrer tá ligado (...) muda assim não vai mudar ninguém, mas pelo menos uma reflexão ali é o que eu tento fazer acontecer (...) tem alunos que pá refletem mesmo de um jeito tipo que nossa mano eu fiz tal coisa e tal e pô não valeu mesmo a pena cara, então vou ficar de boa, arruma um trampo e tal, ao mesmo tempo também que tem uns cara que não eu sou vida loca, eu vou vixi, e se desacreditar de mim te mato também professor, hehe, assim, fita cabulosa, tem os pontos positivos e negativos, é um público muito grande, e muitos casos (JHOW, Oficineiro de Rima no CREAS II).

Algo que me chamou a atenção era uma pergunta feita pelo educador sempre que iniciava um adolescente novo na oficina. Ele questionava "Você já ouviu rap, ouve, ou gosta rap?" E mais interessante ainda foi constatar que quase todos os adolescentes ouvem e/ou gostam de rap. Nas observações da oficina isso ficou nítido, muitos adolescentes chegavam ali já sabendo fazer as rimas "free style", o estilo de rap que o MC compõe na hora.

Eu vejo que eles gostam bastante dos mesmos tipos sabe (...) mais o tipo de música que vão conta bem a realidade memo de periferia, de favela, e também de criminalidade (...) eu boto fé que os moleques assim são bem 
receptivos (...) é do cotidiano deles, eles já tão convivendo bastante com isso também, a maioria gosta mais de ouvir rap, eu pergunto cê escuta rap todo dia né cara? É verdade professor só rap. (...) ai tem uns que gostam, tem uns que já vem já sabendo fazer (JHOW, Oficineiro de Rima no CREAS II).

Em muitas das observações percebi o aspecto recorrente de valorização e incentivo a educação nas falas do oficineiro, apontando aos adolescentes a educação como contraponto da vida 'criminosa'. "Você acha que ser rebelde é vive do crime? Rebeldia mesmo é estudar mano, é um tapa na cara do sistema um mano que nasce pobre que nem nóis que consegue estudar e entra numa faculdade" (JHOW, Oficineiro de Rima no CREAS II). Em entrevista gravada, falando sobre o aspecto da educação Jhow coloca que:

O rap são palavras e um ritmo né, então palavras, a pessoa precisa ler, pra ter
bastante... é que nem eu falo pros moleque falo não mano mas se você ta
numa guerra cê vai com uma pistolinha ali é nove tiro mano, cê vai morrê,
cê vai com uma pistola ou com uma metralhadora né o baguio que tem
mais? Então o conhecimento é isso, quando você vai rimar se você tiver
bastante conhecimento você vai ter muito mais vocabulário, muito mais
rimas, vai conseguir falar muito mais (...) ter o conhecimento pra alguém não
passar a perna em você, porque você sem conhecimento fica muito
vulnerável, então explico bem isso pra eles (...) eu falo que é importante ter o
próprio pensamento, ter o pensamento crítico, se fica vendo muita televisão,
não pratica uma leitura, não tem um bom raciocínio lógico vira marionete,
isso ai que é o mais foda (JHOW, Oficineiro de Rima no CREAS II).

A oficina de rima diferentemente de algumas oficinas práticas em que se vê a materialização do trabalho desenvolvido - como as oficinas de artesanato e reciclarte, por exemplo - não apresenta resultados palpáveis daquilo que o adolescente produz e se isso tem exercido uma influência positiva sobre ele. Diante desse impasse, e na impossibilidade de serem realizadas entrevistas com os próprios adolescentes, utilizei como referência as letras de rap compostas pelos jovens durante a participação na oficina. Por meio da análise das letras é possível verificar que a oficina vem atingindo seu objetivo de levar o jovem infrator a uma reflexão. As letras versam principalmente sobre temas como violência, crime, drogas, preconceito e faltas de oportunidade do sujeito jovem principalmente o jovem da periferia. "Esses temas (...) podem ser caracterizados em linhas gerais em relatos de histórias de vida, narrativas de auto-identidade e narrativas de fatos e acontecimentos, que podem ainda, apresentarem uma forma de exposição negativa ou positiva" (MACEDO, 2010, p. 134).

São vários tipos de violência que acontece

Por causa disso os menor falece 
Isso ocorre porque na educação não se investe

Por falta de oportunidade

A molecada entra na marginalidade

E pro político que roba fica na impunidade

Só quem é pobre vai pra trás das grade

É tudo culpa de um sistema falho

Por isso que fazê a paz é nosso trabalho ${ }^{6}$

Esse é apenas um exemplo das músicas compostas pelos adolescentes na oficina. É possível verificar na letra que o adolescente fala a respeito da falta de oportunidades que o sujeito jovem encontra, seja com o pouco investimento em educação e principalmente em formas de lazer e diversão. $\mathrm{O}$ autor da letra coloca isso como sendo um dos meios de entrada do jovem na marginalidade. Considerando que "a violência emerge como forma de sociabilidade que denota uma linguagem ou narrativa que procura a "integração negada" ou "postergada"” (GADEA, 2014, p. 12), podemos dizer que a prática de infrações e a violência podem ser caracterizadas como uma forma de expressão do sujeito jovem em oposição à falta de oportunidades e formas diferenciadas de lazer.

Spósito (1994) aponta que os espaços de sociabilidade dos sujeitos jovens nas grandes cidades são muito restritos, a rua acaba se tornando para eles o principal ponto de encontro "nos bairros periféricos, nos grandes conjuntos habitacionais, as formas de lazer institucionalizadas ou públicas são praticamente inexistentes. Parte do tempo livre, entre a escola e o trabalho, é gasta em uma área nas ruas”. A rua além de espaço de socialização juvenil é também um local onde a violência atinge adolescentes e jovens na interação com o mundo da delinqüência, do consumo de drogas, do crime, das agressões policiais, principalmente nos bairros periféricos das grandes cidades.

\section{A favela pede paz, violência não da mais}

Mano mata mano larga os livros pega o cano

Esse pequeno trecho de uma letra de rap composta pelos adolescentes reflete acerca da questão da violência em relação à vida na periferia. Além de apontar o fato de que a favela seja o principal cenário onde se explicita a violência, o compositor ainda traz a tona um

\footnotetext{
${ }^{6}$ Manteve-se a grafia original da letra composta pelo jovem.

Revista Labor Fortaleza/CE, jan/jul 2017 Vol. 01, nº 17, p. 42-61 ISSN 1983-5000
} 
problema permanentemente negligenciado e desprezado consensualmente que é fato de que um mano mata o outro. ${ }^{7}$

Divulgando a realidade que permeia a vida do jovem na periferia, o autor nas entrelinhas de sua poesia ainda retoma a questão da educação em contraponto a 'vida criminosa' ao dizer que os manos deixam os livros de lado para pegar um cano, ou seja, uma arma, o adolescente expõe a questão de que deixar a educação ou a escola é uma via de fácil acesso a entrada do jovem na criminalidade, isso remonta a idéia da necessidade de investimento não só em educação como também em formas públicas de lazer.

Fora da escola o jovem encontra a rua como seu principal espaço de convivência. $\mathrm{Na}$ rua o sujeito estabelece diferentes formas de socialização e o rap surge como uma possibilidade de sociabilidade proveniente de um contexto marginalizado. $\mathrm{O}$ rap enquanto forma de sociabilidade dos sujeitos jovens marginalizados, e pelo aspecto da formação de identidade "é um importante elemento na formação de um imaginário sobre a vida na periferia (...) é impossível não perceber as continuidades entre as letras dos raps e os discursos e mesmo práticas dos jovens" (LEITE, 2012, p. 147).

O rap como meio de socialização e forma de expressão juvenil, pode contribuir na ressignificação do contexto de jovens e adolescentes (em cumprimento de medida socioeducativa ou não) na perspectiva de que o estilo de vida rap (...) possibilitou a muitos desses jovens uma ampliação significativa do campo de possibilidades, abrindo espaços para sonharem com outras alternativas de vida que não aquelas, restritas, oferecidas pela sociedade (DAYRELL, 2002, 134).

É certo que os verdadeiros impactos sobre os adolescentes só poderiam ser verificados com um acompanhamento efetivo do contexto da vida prática a partir da realização de uma pesquisa etnográfica, que não nos cabe no momento, porém mediante as leituras realizadas e a partir da análise da oficina de rima é possível afirmar que o rap pode sim contribuir para ressignificar o contexto de jovens e adolescentes em cumprimento de medida socioeducativa.

\footnotetext{
${ }^{7}$ É recorrente nos discursos midiáticos a ideia positiva sobre a morte de um jovem de periferia, principalmente se o este jovem possui passagens pela polícia. Consensualmente criou-se a falsa perspectiva de que o sujeito infrator, ou que possui algum envolvimento com drogas deve morrer, e isso se torna ainda mais 'natural' quando a morte é posta como "acerto de contas" pelo tráfico de drogas.

Revista Labor Fortaleza/CE, jan/jul 2017 Vol. 01, n 17, p. 42-61 ISSN 1983-5000
} 


\section{CONSIDERAÇÕES FINAIS}

Quando objetivamos estudar o gênero musical rap, não se tinha noção das inúmeras questões e desafios que a pesquisa traria. A articulação do tema com as culturas juvenis, o conceito de juventude e a questão da violência vieram nas entrelinhas e de maneira inescapável não puderam ser deixadas de lado. Isso denota que de fato nunca se sabe tudo sobre algo, o conhecimento é inesgotável.

Levando em consideração o rap enquanto uma cultura juvenil, oriunda de processos de socialização e entendendo-o como um instrumento influente na formação de identidades, nosso objetivo foi estudá-lo como possibilidade educativa na ressignificação do contexto de jovens e adolescentes em cumprimento de medida socioeducativa na cidade de Cascavel.

A partir das observações realizadas na oficina de rimas, algumas questões estudadas teoricamente puderam ser analisadas, como o aspecto de formação de identidade a partir do gênero musical rap, bem como o envolvimento e a identificação dos sujeitos jovens com esse estilo. Tal identificação foi perceptível não apenas na reprodução de letras de canções ou no fato de que os adolescentes chegavam à oficina sabendo "fazer rap", mas também no aspecto da vestimenta, no modo de falar, entre outros, que apontam para o compartilhamento de valores e significações em relação ao movimento hip hop de maneira geral.

No que se refere à análise da relação entre violência e juventude, ela foi colocada como uma necessidade a partir do momento em que se definiu como objeto de pesquisa sujeitos jovens circunstancialmente envolvidos com a prática de infrações. A pesquisa foi extremamente importante nesse ponto, pois foi possível desconstruir preconceitos e falsas ideologias tão alardeadas pela mídia, de que os jovens são os principais envolvidos com práticas de violência e a 'vida do crime'. Isso foi verificado ainda nos próprios dados coletados durante a pesquisa de campo no CREAS II, sobre aos atos infracionais que levaram a aplicação da medida socioeducativa na cidade de Cascavel no ano 2015. Os dados deixam claro que o discurso midiático sobre a relação dos jovens com a prática de crimes 'pesados' é uma falácia, e que tal discurso tem sido um valioso instrumento de descaracterização dos sujeitos jovens como seres de direitos e não reconhecidos socialmente.

A pesquisa também contribuiu na compreensão da necessidade de elaboração de políticas públicas voltadas à juventude. Políticas que dêem aos jovens visibilidade e lugar na 
sociedade e que verdadeiramente sejam promotoras dos direitos desses sujeitos, principalmente no diz respeito a espaços para lazer e educação de qualidade, tendo em vista que na observação da oficina de rima esses aspectos foram inúmeras vezes apontados pelos adolescentes e até mesmo ressaltados nas letras de rap por eles compostas.

No que diz respeito ao aspecto educativo, ficou claro na observação da oficina e na entrevista realizada com o oficineiro e a pedagoga do CREAS, de que o rap pode ser caracterizado uma possibilidade educativa e em muito pode contribuir na ressignificação do contexto de jovens e adolescentes que cumprem medida socioeducativa. Utilizar o rap como instrumento educativo num espaço de institucionalização é partir de uma prática social contextualizada, visando desprender a educação de aspectos formalizados e homogeneizadores, permitindo ao jovem expressar sua condição juvenil.

O rap como possibilidade educativa pode significar de acordo com Dayrell

(...) uma referência na elaboração e vivência da condição juvenil, contribuindo de alguma forma para dar um sentido à vida de cada um, num contexto onde se vêem relegados a uma vida sem sentido. Ao mesmo tempo, o estilo de vida rap (...) possibilitou a muitos desses jovens uma ampliação significativa do campo de possibilidades, abrindo espaços para sonharem com outras alternativas de vida que não aquelas, restritas, oferecidas pela sociedade. Querem ser reconhecidos, querem uma visibilidade, querem ser alguém num contexto que os torna invisíveis, ninguém na multidão. Querem ter um lugar na cidade, usufruir dela, transformando o espaço urbano em um valor de uso. Enfim, querem ser jovens e cidadãos, com direito a viver plenamente a sua juventude (DAYRELL, 2002, p. 134).

A presente pesquisa me trouxe inquietações para ir além. Esta, que deveria ser o meu ponto de chegada, acaba por fim sendo apenas um ponto de partida daquilo que poderá trazer inúmeros desdobramentos para realização de outras pesquisas.

\section{REFERÊNCIAS}

BRASIL. Lei no 8069, de 13 de julho de 1990. Estatuto da Criança e do Adolescente. Brasília, DF, 13 jul. 1990. Disponível em: <http://www.planalto.gov.br/ccivil_03/LEIS/L8069.htm>. Acesso em: 4 maio 2015.

DAYRELL, Juarez. O rap e o funk na socialização da juventude. Educação e Pesquisa, São Paulo, v. 28, n. 1, p.117-136, jan./jun. 2002. [Documento Eletrônico]. Disponível em: <http://www.scielo.br/pdf/ep/v28n1/11660.pdf>. Acesso em: 28 mar. 2014.

. O jovem como sujeito social. Revista Brasileira de Educação, Rio de Janeiro, n. 24, p. 40-52, abr. 2003. Trimestral. [Documento Eletrônico] Disponível em: <http://www.scielo.br/pdf/rbedu/n24/n24a04>. Acesso em: 16 maio 2015. 
DIÓGENES, Glória Maria dos Santos. Cartografias da cultura e da violência: gangues, galeras e o movimento Hip Hop. 1998. 381 f. Tese (Doutorado) Universidade Federal Do Ceará. [Documento Eletrônico]. Disponível em:

$<$ http://www.repositorio.ufc.br/bitstream/riufc/4060/1/1998_Tese_GMSDiogenes.pdf>Acesso em: 28 nov. 2015.

ESTEVES, Luiz Carlos Gil; ABRAMOVAY, Miriam. Juventude, juventudes: pelos outros e por elas mesmas. In: VI CONGRESSO PORTUGUÊS DE SOCIOLOGIA - Mundos Sociais: Saberes e Práticas, $n^{\circ}$ 254. 2008, Lisboa. [Documento Eletrônico] Disponível em: <http://www.aps.pt/vicongresso/pdfs/254.pdf>. Acesso em: 20 jul. 2015.

FACHINETTO, Rochele Fellini. Juventude e violência: onde fica o jovem numa sociedade "sem lugares?". In: A violência na sociedade contemporânea. Org. Maria da Graça Blaya Almeida. - Porto Alegre: EDIPUCRS, 2010. 161 f. Disponível em:

<http://ebooks.pucrs.br/edipucrs/violencia.pdf> Acesso em: $22 \mathrm{dez} .2015$.

FIUZA, Alexandre Filipe; MACEDO, Iolanda. A educação informal e o rap como agente educativo. Eccos Revista Científica, São Paulo, n. 31, p.17-32, maio/ago. 2013. [Documento Eletrônico]. Disponível em: <http://www.redalyc.org/pdf/715/71529334002.pdf>. Acesso em: 27 ago. 2015.

GADEA, Carlos. Itinerários juvenis em situação de vulnerabilidade social: sobre a realidade juvenil e a violência intersubjetiva e o impacto dos Centros POD Juventude em Porto Alegre (RS). In: $37^{\circ}$ ENCONTRO ANUAL DA ANPOCS, 2013, Águas de Lindóia. [Documento Eletrônico]. Disponível em:

http://www.anpocs.org/portal/index.php?option=com_docman\&task=doc_view\&gid=8591\&I temid=459>. Acesso em: 02 nov. 2015.

Jovens, violência e contemporaneidade: interpretações e desafios da escola. In:

Violência e Educação: Em busca de novos olhares. Org. Vilmar Malacarne et al. Curitiba: CRV, 2014. p. 229.

GOHN, Maria da Glória. EDUCAÇÃO NÃO FORMAL E CULTURA

POLITICA: impactos sobre o associativismo do terceiro setor. 5. ed. São Paulo: Cortez, 2011. $128 \mathrm{p}$.

HALL, Stuart. A identidade cultural na pós-modernidade. 11. ed. Rio de Janeiro: Dp\&a Editora, 2006. 102 p. [Documento Eletrônico]. Disponível em:

<http://www.cefetsp.br/edu/geo/identidade_cultural_posmodernidade.doc.>. Acesso em: 04 out. 2015.

LEITE, Tiago Pereira. Entre nóias, playboys e a galera da vila: uma etnografia das relações sociais entre jovens da periferia de Paranaguá - PR. 2012. 176 f. Dissertação (Mestrado) Curso de Centro de Ciências Sociais e Humanas, Universidade Estadual do Oeste do Paraná/campus de Toledo, Toledo, 2012. [Documento Eletrônico] Disponível em: <http://200.201.88.199/portalpos/media/File/ciencias_sociais/Disserta\%C3\%A7\%C3\%A3o\% 20Tiago\%20Pereira\%20Leite.pdf>. Acesso em: 22 dez. 2015. 
MACEDO, Iolanda. O discurso musical rap: expressão local de um fenômeno mundial e sua interface com a educação. 2010. 230 f. Dissertação (Mestrado) - Universidade Estadual do Oeste do Paraná - Cascavel, 2010. [Documento Eletrônico]. Disponível em: <http://erevista.unioeste.br/index.php/temposhistoricos/article/view/5708/4285.>. Acesso em: 28 mar. 2014.

MAGNANI, José Guilherme Cantor. Os circuitos dos jovens urbanos. Tempo Social: revista de sociologia da USP, [São Paulo], v. 17, n. 2, p.173-205, nov. 2005. Semestral. [Documento Eletrônico]. Disponível em: <http://www.scielo.br/pdf/ts/v17n2/a08v17n2.pdf>. Acesso em: 9 ago. 2015.

SANTOS, Luana Isabelle Cabral dos. Et al. Juventude e violência: trajetórias de vida e políticas públicas. Estudos e Pesquisas em Psicologia, Rio de Janeiro, v. 12, n. 2, p. 521538, 2012. [Documento Eletrônico]. Disponível em: <

http://www.revispsi.uerj.br/v12n2/artigos/pdf/v12n2a12.pdf> Acesso em: 18 dez. 2015.

SCHROEDER, Tania Maria Rechia. Violência Escolar: O movimento entre as forças da ordem e da desordem. Educação e cidadania, [S.1.], p. 1-10, 2008. Disponível em:

$<$ http://seer.uniritter.edu.br/index.php/educacaoecidadania/article/view/140/66>. Acesso em: nov. 2016.

SILVA, Cristiane Rodrigues; SILVA, Pâmela Costa da. Juventude e cultura: reflexões acerca das culturas juvenis no currículo escolar. Artifícios: Revista do Difere, Pará, v. 2, n. 3, p.117, ago. 2012. Semestral. [Documento Eletrônico]. Disponível em:

<http://www.artificios.ufpa.br/Artigos/artigo cris.pdf>. Acesso em: 5 ago. 2015.

SPOSITO, Marília Pontes. A sociabilidade juvenil e a rua: novos conflitos e ação coletiva na cidade. Tempo Social: revista de sociologia da USP, São Paulo, v. 5, n. 1-2, p.161-178, nov. 1994. [Documento Eletrônico]. Disponível em:

<http://www.fflch.usp.br/sociologia/temposocial/site/images/stories/edicoes/v0512/Sociabilid ade.pdf $>$. Acesso em: 19 ago. 2015.

TITON, Andréia Piana. ZANELLA, Andréa Vieira. Jovens de Classes Populares e Suas Relações na/com a cidade De Florianópolis/Sc. In: I Seminário Violar Problematizando as Juventudes na Contemporaneidade, 2010, Campinas. Anais. Campinas, Unicamp, 2010. p. 31 - 46. [Documento Eletrônico]. Disponível em:

<https://www.fe.unicamp.br/semviolar/anais/Anais-ISemViolar.pdf>. Acesso em: 11 set. 2015.

VIANA, Nildo. Juventude e Identidade. Estudos, Goiânia, v. 36, n. 1-2, p.145-154, jan./fev. 2009. Bimestral. [Documento Eletrônico] Disponível em:

<http://seer.ucg.br/index.php/estudos/article/viewFile/1022/720..>. Acesso em: 04 out. 2015.

WAISELFISZ, Julio Jacobo. Mapa da Violência 2014 - Os jovens dos Brasil. Flacso. Brasília, 2014. 